\title{
Sveti Toma u enciklici Fides et ratio
}

\author{
Serge-Thomas Bonino, OP*
}

\begin{abstract}
Sažetak
Odlomci enciklike Fides et ratio koji su izričito posvećeni sv. Tomi Akvinskomu tvore svojevrsni zgusnuti sažetak, odnosno sintezu cjelokupne enciklike. Ti odlomci sadrže glavne teme koje su razrađene u drugim dijelovima enciklike (filozofija otvorena vjeri, teologija pozorna na filozofiju i $d r$.). Naučavanje enciklike o ulozi tradicija u intelektualnom životu daje opravdanje stalnih preporuka Crkve o povlaštenom nauku sv. Tome, kako u filozofiji, tako i u teologiji.

Ključne riječi: filozofija, teologija, tomizam, metafizika, mudrost, tradicija, vjera i razum
\end{abstract}

\section{Uvod}

Htio bih u prigodi kada obilježavamo dvadesetu obljetnicu enciklike izložiti dvije teze o mjestu sv. Tome Akvinskoga u enciklici Fides et ratio. Prva je teza da odlomci koji su eksplicitno posvećeni sv. Tomi čine neku vrstu „koncentrata” ili sažetka cijele enciklike. Oni ilustriraju važne teme koje se razvijaju u ostalim dijelovima enciklike. Druga je teza da nauk enciklike, i to prilično nov, o ulozi predaja u intelektualnom životu iznosi vjerojatno najbolje opravdanje za činjenicu da Crkva stalno preporuča nauk sv. Tome kao privilegiran podjednako u filozofiji i teologiji.

\section{Sažetak enciklike}

\subsection{Mjesta na kojima se spominje sv. Toma}

Referencije na sv. Tomu u enciklici koncentrirane su na tri temeljna mjesta. ${ }^{1}$ Prvu cjelinu čine brojevi 43-44 objedinjeni pod naslovom Trajna novost misli sv. Tome Akvinskoga. Ta dva broja nalaze se u središtu 4. poglavlja, u kojem sv.

* Prof. dr. sc. Serge-Thomas Bonino OP, dekan Filozofskoga fakulteta Papinskoga sveučilišta sv. Tome Akvinskoga (Angelicum) u Rimu, generalni je tajnik Međunarodne teološke komisije, predsjednik Papinske akademije sv. Tome Akvinskoga. Adresa: Largo Angelicum 1, 00184 Rim, Italija. E-adresa: stbonino@gmail.com 
Ivan Pavao II. prepričava povijest odnosa kršćanske vjere i razuma, od njihova (turbulentnoga) susreta na Areopagu do danas. Samim svojim položajem u ekonomiji toga poglavlja sv. Toma javlja se kao kruna »glavnih koraka pri susretu vjere i razuma« (opisanih u prvom dijelu poglavlja u FR 36-42) prije »tragedije vjere odvojene od razuma « (opisane u drugom dijelu poglavlja, FR 45-48), koja dovodi do aktualne krize filozofije. Sv. Toma tu nije predstavljen kao provizorno povijesno uporište, nego kao trajan model.

Drugo mjesto na kojem enciklika spominje sv. Tomu nalazi se u 5. poglavlju, kada se govori o »prosudbama učiteljstva u filozofijskom području «. U prvom se dijelu poglavlja rekapituliraju upozorenja učiteljstva o filozofijskim pogreškama koje su prijetile vjeri (FR 48-56), a u drugom se dijelu podsjeća na »zanimanje Crkve za filozofiju « (FR 57-63), kao i na poticaje koje je Crkva dala filozofijskim istraživanjima. Taj drugi dio 5. poglavlja započinje baš naglašavanjem odlučujuće uloge učiteljstva u tomističkoj obnovi 19. stoljeća (FR 57-58) i nastavlja naglašujući trajnu podršku Crkve poučavanju tomizma od toga doba nadalje (FR 60-61).

Treće mjesto na kojem se u enciklici spominje sv. Toma govori baš o toj zauzetosti učiteljstva, i to na pomalo minimalistički način: »Nakana učiteljstva je bila i jest da naznači kako je sv. Toma rođeni primjer svima onima koji traže istinu« (FR 78).

\subsection{Vjera i razum}

Osim navođenja mjesta na kojima se spominje sv. Toma, valja posebno naglasiti sadržaj nauka enciklike Fides et ratio o sv. Tomi. U tom svjetlu, odlomci posvećeni sv. Tomi podsjećaju na fraktalne strukture o kojima govore matematičari, a u kojima se struktura cjeline na identičan način reproducira u svakom od svojih sastavnih dijelova. Točnije, razrade koje Ivan Pavao II. posvećuje sv. Tomi Akvinskomu sažimlju i odražavaju kao u zrcalu glavne točke nauka enciklike. To prije svega vrijedi za središnju temu odnosa između vjere i razuma.

Doista, intimna i plodna veza između vjere i razuma koju priziva enciklika nije utopija. Ona je konkretna povijesna stvarnost koju možemo prepoznati kod sv. Tome. Točnije, »njegova najveća zasluga bila je u tome što je učinio da se istakne sloga između razuma i vjere« (FR 43). I to u tolikoj mjeri da je Crkva u nauku Zajedničkoga Naučitelja o toj temi prepoznala izraz vlastite vjere, kao što tomu, primjerice, svjedoči sadržajna ovisnost konstitucije Dei Filius Prvoga vatikanskoga koncila o prvim poglavljima Sume protiv pogana, u kojoj Akvinac izlaže odnose između vjere i razuma.

»Svjetlo jednoga i drugoga, to jest razuma i vjere ${ }^{2}$ proizlazi od Boga, zaključivaše on, dakle, oni se ne mogu međusobno suprotstavljati« (FR 43). Unatoč

1 Ovaj je rad izmijenjeno i dopunjeno istoimeno predavanje koje je održano u Zagrebu 2. listopada 2018. na međunarodnom znanstveno skupu Fides et ratio — Vjera i razum: 20 godina poslije, povodom 20. obljetnice enciklike pape Ivana Pavla II. Fides et ratio. Znanstveni skup su organizirali Fakultet filozofije i religijskih znanosti Sveučilišta u Zagrebu, Institut sv. Tome Akvinskoga i Filozofski fakultet Papinskoga sveučilišta sv. Tome Akvinskoga u Rimu (Angelicum). S francuskoga prevela Marta Petrak.

2 Citirano je 7. poglavlje prve knjige Sume protiv pogana. 
tomu, to ostaju dva različita svjetla — odnosno dva različita načina spoznavanja. Filozofija, koja pokreće naravno svjetlo razuma, i teologija, koja nalazi uporište u nadnaravnom svjetlu vjere, ne miješaju se i stoga se mogu razvijati svaka prema vlastitoj metodi i u vlastitom smjeru. U enciklici Aeterni Patris, Lav XIII., koji je citiran u enciklici Fides et ratio, već je naglasio trajnu valjanost toga razlučivanja između vjere i razuma, »izvrsno razlikujući, kao što i treba, razum od vjere, [sveti ih je Toma] oboje ipak prijateljski združio te sačuvao prava jednog i drugog i pobrinuo se za njihovo dostojanstvo« (FR 57). Tako su prema enciklici Fides et ratio u razmišljanju sv. Tome »zahtjevi razuma i snaga vjere pronašli najdublju sintezu koju je ljudsko mišljenje ikad doseglo, zato što je korjenito čuvao osobitost objave, a da nikad nije ponižavao put koji je vlastit razumu« (FR 78).

Kod sv. Tome razum ne proždire vjeru svodeći je na svoju vlastitu mjeru. No ni vjera ne čini filozofijsku racionalnost beskorisnom. Suprotno tomu, »Sv. Albert Veliki i sv. Toma [...] bili su prvi učenjaci koji su priznali nužnu autonomiju potrebnu filozofiji i znanostima da bi se one, svaka u svojem području, prihvatile vlastitoga istraživanja (FR 45).

Imajući to u vidu, kod sv. Tome formalna i opravdana razlika između filozofijskoga razuma i vjere nikada ne prelazi u razdvojenost, koja bi bila smrtonosna. Akvinac je znao održati »organsku vezu između teologije i filozofije « (FR 45) u korist i jedne i druge. Počnimo s prednostima koje iz toga vuče filozofija.

\subsection{Filozofija otvorena vjeri}

Filozofija ne može doprijeti do svoje punine osim pod ravnanjem vjere u mjeri u kojoj milost, kao gratia elevans, ne otvara razumu samo nove horizonte, nego ponajprije, kao gratia sanans, također vraća ranjen razum njemu samomu. »Kao što milost pretpostavlja narav i usavršuje ju, tako vjera pretpostavlja i usavršuje razum. Razum, obasjan svjetlom vjere, oslobođen je slabosti i ograničenja koja proizlaze iz počinjenoga grijeha« (FR 43). Samo u takvom povoljnom ozračju filozofsko razmišljanje može se u potpunosti razviti. Sveti se Toma tu pojavljuje kao jedan od »velikih kršćanskih teologa koji su se također istaknuli i kao iznimni filozofi, a ostavili su spise tako duboke spekulativne vrsnoće da ih s pravom izjednačujemo učiteljima stare filozofije« (FR 74), baš zato što su bili teolozi.

To nije nimalo začuđujuće znamo li da filozofija kod sv. Tome na uzoran način odgovara trima zahtjevima koje enciklika stavlja pred svaku autentičnu filozofiju: završetak u istini, metafizičku otvorenost i mudrosnu dimenziju (usp. 7. poglavlje). Pozivajući se na encikliku Aeterni Patris, u enciklici Fides et ratio primijećeno je da se »obnavljanje nauke Anđeoskog Naučitelja činilo papi Lavu XIII. najboljim putem da se vrati ona uporaba filozofije koju je zahtijevala vjera« (FR 57).

\subsubsection{Istina}

Prvo što se u enciklici Fides et ratio zahtijeva od filozofije jest da izbjegava »rasuto tlo sveopćeg skepticizma« (FR 5), odnosno da prizna postojanje objektivne istine i mogućnosti da ju ljudski um sa sigurnošću spozna (FR 82). Dakako, 
Ivan Pavao II. bio je svjestan da vježbanje mišljenja zahtijeva teška posredovanja (počevši od posredovanja jezika), te da je to vježbanje u velikoj mjeri uvjetovano povijesnim i kulturnim okolnostima. Otuda proizlazi nužna hermeneutika. No papa nije ništa manje bio uvjeren da ta uvjetovanja ne zatvaraju pristup spoznaji objektivne i univerzalne istine, koja je sam predmet proučavanja filozofije. Točnije, pozivajući se na vrlo poznati citat komentara In de Caelo sv. Tome, u enciklici se smatra da »specifičan prinos filozofijske misli daje da se u različitim mišljenjima o životu i u kulturama shvati 'ne ono što su ljudi mislili, nego kakva je istina stvari' « (FR 69). Taj su tekst neki neotomisti, opsjednuti historicizmom nažalost koristili protiv povijesnoga studija djela sv. Tome. No sama praksa sv. Tome svjedoči da je proučavanje »onoga što ljudi misle« privilegiran put za dospijevanje do objektivne istine (a u nastavku se još vraćamo na to). Unatoč svemu, ostaje, kako navodi enciklika, da pokretač i krajnji cilj filozofskoga istraživanja mora biti spoznaja veritas rerum.

U toj perspektivi u Fides et ratio hvaljen je „realizam” sv. Tome, odnosno uvjerenje da čovjek ima sposobnost »postizanja spoznaje istine; to je spoznaja koja dolazi do objektivne istine pomoću podudarnosti stvari i uma (adaequatio rei et intellectus), kako su to nazivali učitelji skolastike «(FR 82). Zahvaljujući tomu realizmu, kojim »je uvijek potvrđivao univerzalnu objektivnu i transcendentnu istinu « (FR 44), sv. Tomu »može se s pravom nazvati 'aspostolom istine' « (FR 44), prema izrazu Pavla VI. iz apostolskoga pisma Lumen Ecclesiae (1974). Anđeoski Naučitelj umio je rasvijetliti, podjednako sadržajem i izrazom svojega naučavanja, dva temeljna svojstva istine. Prije svega, istina je objektivna (FR 44). Ona nije izraz ili odraz moje vlastite subjektivnosti, nego odgovara stvarnosti. Nadalje, istina vrijedi za sve. Ona je univerzalna. Posljedično, istinu treba tražiti svugdje gdje se ona nalazi, po primjeru sv. Tome, »duboko uvjerenog da omne verum a quocumque dicatur a Spiritu Sancto est,${ }^{4}$ sveti Toma [...] tražio je istinu gdjegod se mogla pokazati«(FR 44). On je želio posvuda, čak i iz najmanjkavijih filozofija, prikupiti i najmanju česticu istine. Želio je spasiti ono što je Maritain nazvao »zasužnjenim istinama «, 5 vadeći ih iz njihova izvornoga konteksta kako bi ih uklopio u određenu sintezu koja im daje njihovo puno značenje. Otuda proizlazi njegova praksa intelektualnoga dijaloga, primjerice $» s$ arapskim $i$ hebrejskim naučavanjem« (FR 43).

\subsubsection{Metafizika}

Realizam sv. Tome omogućava također da se zadovolji drugi zahtjev koji stoji pred svakom filozofijom koja je otvorena vjeri: a to je njezina navlastita metafizička dimenzija, odnosno njezina sposobnost da »nadilazi iskustvene danosti

3 »Studium philosophiae non est ad hoc ut sciatur quid homines senserint, sed qualiter se habeat veritas rerum « (Toma Akvinski, 1952; I, lect. 22, n. 8). U prijevodu: »Filozofija se ne proučava radi toga da se zna što su ljudi mislili, nego što je istina u zbilji« (Toma Akvinski, 2005, 70).

4 Prijevod s latinskoga: »Sve istinito, tko god to rekao, dolazi od Duha Svetoga

5 Sintagmu „zasužnjene istine” (vérités captives) Jacques Maritain rabi u odgovoru Jeanu Cocteauu, 1926. godine (Maritain, 1984, 724). 
tako da, tražeći istinu, može doprijeti do nečega apsolutno krajnjega i temeljnoga« (FR 83), što ne može biti ništa drugo doli sam bitak, navlastiti predmet metafizike. Prema mišljenju sv. Ivana Pavla II., velika napast moderne filozofije nalazi se u zatvaranju u beskrajno razmatranje o samom spoznajnom subjektu, pri čemu se zanemaruje njegova zadana otvorenost spram objekta, njegova sposobnost spoznaje onoga što je stvarno, kao i sposobnost da iz toga sabire smisao stvari i vlastitoga života. Um se ne ograničava na doticanje površine stvari. On se ne zaustavlja na pojavnostima, nego može prodrijeti do najdubljega otajstva stvari, odnosno do njihove same biti pomoću koje se stvari povezuju s Božjim apsolutom. Metafizika, kao filozofija bitka, »svoj trajni poticaj nalazi u tome da se temelji na samom činu 'bitka' (actus essendi) odakle se dopušta potpuno i sveopće otvaranje prema svoj zbilji, otvaranje koje nadilazi sve granice tako da se dosegne Onaj koji svakoj stvari daje njezino ispunjenje« (FR 97). Ta se metafizička otvorenost na poseban način vrednuje u tomizmu. Stavljajući u svoje središte actus essendi (eksplicitno spomenut u FR 97), tomizam je »zaista filozofija bitka (essendi), a ne pukog pojavka (apparendi)«(FR 44).

\subsubsection{Mudrosna perspektiva}

Napokon, treći zahtjev upisan u svojstva autentične filozofije taj je da ne napušta vrhunce radi krtičnjaka (FR 81). Papa potiče filozofe na velikodušnost jer filozofija nema pravo zaobići »temeljna pitanja o smislu i zadnjem temelju ljudskoga osobnog i društvenog života « (FR 5) kako bi se (pod izlikom poniznosti) povukla u sekundarne, puko sektorske probleme ili u proučavanje vlastite povijesti. U skladu sa svojom etimologijom, filozofija se ne može odreći traganja za mudrošću, odnosno sintetičke spoznaje krajnjega smisla stvari i života. Usredotočujući se na otajstvo bitka razmatrano u svoj njegovoj transcendentnoj širini, sv. Toma uspijeva obuhvatiti ukupnost stvarnoga u svjetlu prvih načela i uzdići se sve do spoznaje Boga kao subzistirajućega Bitka, ostvarujući tako mudrosni poziv filozofije.

\subsection{Teologija otvorena filozofiji}

Iako se filozofija kod sv. Tome okoristila od svoje veze s vjerom, teologija je također mnogo dobila u smislu da je Akvinac, kao teolog, svjedočio filozofijsku istinu. U stvari, enciklika inzistira da razumijevanje vjere ne može postojati bez filozofije, koja i sama mora biti postojana. »Toma [...] pokazuje kako priroda, navlastiti predmet filozofije, može pridonijeti razumijevanju Božje objave. Vjera se, dakle, ne boji razuma nego ga traži i pouzdaje se u njega (FR 43). Kritička pozornost kojom je sv. Toma promatrao filozofijska kretanja svojega vremena i njegova trajna briga da u samom svojem teologijskom usavršava filozofijski instrument koji je primjenjivao odlučujući su motivi zbog kojih je »sveti Toma od Crkve stalno bio smatran Učiteljem nauke i primjerom kako se treba baviti teologijom« (FR 43) te »voditeljem teološkoga studija $«(F R ~ 78)$. 
No Ivan Pavao II. ne propušta podsjetiti, u FR 44, da tomistička ravnoteža između vjere i razuma nalazi svoje najsigurnije uporište $u$ »prvenstvu one mudrosti koja je dar Duha Svetoga i koja vodi do spoznaje božanskih stvari« (FR 44). Upravo u vitalnom kontekstu otajstvene mudrosti filozofijska mudrost i teologijska mudrost mogu se razvijati i surađivati na najbolji način. Ta pozornost posvećena konkretnomu načinu filozofiranja dovodi nas do naše druge teze.

\section{Razmišljati u predaji: smisao nauka sv. Tome}

Enciklika Fides et ratio označava prilično novo shvaćanje uloge predaje kao privilegiranoga načina kojim čovjek dolazi do spoznaje istine. Ljudska osoba, ustvari, ne dolazi do punine svoje ljudskosti, a napose do spoznaje univerzalne istine, drukčije doli posredstvom svojega ulaženja u određenu kulturnu i doktrinarnu tradiciju. Ističući činjenicu da se »u današnjim prilikama neki filozofi pokazuju promicateljima nanovo otkrivene velike važnosti predaje za pravilni oblik spoznaje « (FR 85), sv. Ivan Pavao II. više puta naglašava da „vjerovanje”, koje implicira odnos prema predaji, čini dio traganja za istinom, bilo u filozofiji ili, još i više, u teologiji, jer teologija nije »razmišljanje pojedinih ljudi [...], nego bogatstvo zajedničkoga razmišljanja. Naime, teologija je u istraživanju istine po samoj svojoj naravi poduprta značajkom eklezijalnosti te isto tako predajom Božjega naroda s njezinom raznovrsnošću znanjâ i kulturâ u jedinstvu vjere« (FR 101). Kako bi pokazao da nadnaravni čin vjere nije anomalija, nego dovodi do ispunjenja jedan način pristupanja istini koji je već prisutan u naravnom poretku, papa naglašava duboku antropološku prikladnost »razmišljanja u skladu s predajom «: »Vjera se često pokazuje bogatijom od jednostavne očevidnosti, jer sa sobom nosi međuosobni odnos i uvodi u igru ne samo osobne razumske sposobnosti, nego i dublju sposobnost da sami povjerujemo drugim osobama, uspostavljajući s njima čvršći i intimniji odnos « (FR 32). Ukratko, »razmišljati u skladu s predajom «, što pokreće ne samo umne sposobnosti, nego i cijeli egzistencijalni poredak, daleko je očovječujuće od pojedinačnoga traženja subjektivne izvjesnosti. Ta rehabilitacija predaje označava dobrodošli prekid s modelom racionalnosti naslijeđenim od modernoga racionalizma, modelom koji je nažalost protunaravno zaveo kršćansku misao. Upravo se tako određeni neotomizam, opsjednut apologetikom, a da to nije ni primijetio, našao na neprijateljskom terenu i usvojio jedan oblik racionalnosti usredotočen na model odvojene filozofije, uvelike suprotstavljene specifičnostima kršćanske racionalnosti.

\section{Zaključak}

Naglasak koji je u enciklici Fides et ratio stavljen na važnost predaje tiče se sv. Tome na dvojak način. Prvo, on oživljava aktualnost tomističke antropologije. Naime, nije sva antropologija u stanju objasniti odlučujuću ulogu predaje $\mathrm{u}$ intelektualnom i kulturnom izgrađivanju ljudske osobe. Primjerice, dualistič- 
ka antropologija kartezijanskoga tipa spontano se je nastojala odmaknuti u apstraktan univerzalizam, odnosno u ljudskoj osobi razdvojiti (univerzalni) razum od tjelesnosti, koja je izvor konkretne društvene i povijesne ukorijenjenosti. Suprotno tomu, kršćanska antropologija sv. Tome Akvinskoga, budući da uzima za ozbiljno tjelesnu uvjetovanost ljudske spoznaje, sposobna je pomiriti dimenziju ukorijenjenosti i dimenziju otvorenosti, koje zajednički definiraju strukturu tradicijske misli.

Nadalje, važnost koja se pridaje predaji u intelektualnom životu objašnjava upornost kojom Učiteljstvo pokazuje sv. Tomu ne samo kao (častan, ali nadiđen) uzor usklađivanja vjere i razuma, nego i kao uvijek aktualnoga učitelja sposobna uvesti one koji se uzdaju u »tomističku predaju « (FR 58) s njezinim različitim „školama” u umnost tradicionalne baštine kršćanske mudrosti. Tako je u enciklici Fides et ratio ponovljen neodložan poziv Crkve da se »ustraje na shvaćanju njegove filozofije« (FR 61), a sv. Ivan Pavao II. izražava žaljenje »što propisi učiteljstva nisu uvijek obdržavani željenom spremnošću« (FR 61).

Naravno, »Crkva ne [...] preporuča bilo koju pojedinačnu filozofiju na štetu drugih« (FR 49). Ona nastoji poštovati određen teološki pluralizam, koji je podjednako filozofijski i teologijski. Nije, dakle, točno predstavljati tomizam kao službenu filozofiju ili teologiju Crkve. Ipak, na temelju razboritoga rasuđivanja "dozreloga" kroz višestoljetno iskustvo koje nije lišeno pomoći Duha Svetoga, Crkva preporuča, i to napose svojim budućim svećenicima, studij svetoga Tome kao konkretan, siguran i iskušan put ne samo za ulazak u primamljiv um baštine kršćanske mudrosti, nego i kao put njezine aktualizacije u današnjem vremenu.

\section{Literatura:}

FR. Fides et ratio. Ivan Pavao II., Fides et ratio: Vjera i razum: Enciklika svim biskupima Katoličke crkve o odnosu vjere i razuma. Zagreb: Kršćanska sadašnjost, 1999.

Maritain, Jacques et Raïssa (1984). Euvres complètes: Volume III: 1924-1929. Paris: Editions Universitaires.

Toma Akvinski (1952). In Aristotelis libros de caelo et mundo. Torino: Marietti.

Toma Akvinski (2005). Izabrano djelo. Drugo prošireno izdanje priredio Anto Gavrić. Zagreb: Nakladni zavod Globus. 
Saint Thomas in the Encyclical Fides et Ratio

Serge-Thomas Bonino, O.P.*

Summary

The paragraphs contained in the encyclical Fides et Ratio which are explicitly devoted to Saint Thomas Aquinas comprise a condensed summation, or rather synthesis of the entire encyclical. These paragraphs incorporate the main themes which are expounded in other sections of the encyclical (philosophy opened to faith, theology mindful of philosophy, etc.) Encyclical teachings on the role of tradition in intellectual life justifies the constant recommendations of the Church regarding the favoured teachings of Saint Thomas, as in philosophy, so too in theology.

Key words: philosophy, theology, Thomism, metaphysics, wisdom, tradition, faith and reason

* Prof. Serge-Thomas Bonino O.P., Ph.D., Dean of the Faculty of Philosophy of the Pontifical University of St. Thomas Aquinas (Angelicum) in Rome, General Secretary of the International Theological Commission, President of the Papal Academy of St. Thomas Aquinas. Address: Largo Angelicum 1, 00184 Rome, Italy. E-mail: stbonino@gmail.com 